\title{
Geloof, etnisiteit en kontekstualiteit: 'n Ondersoek na hulle relasie en relevansie vir kerk- en Christenwees
}

\author{
J.H. van Wyk \\ Skool vir Kerkwetenskappe \\ Potchefstroomse Universiteit vir $\mathrm{CHO}$ \\ POTHEFSTROOM \\ E-pos: amievw@intekom.co.za
}

\begin{abstract}
Faith, ethnicity and contextuality. An investigation of their relation and relevance for the church and for being Christian

In this article the author investigates the relationship between faith, ethnicity and contextuality. In the line of argumentation the viewpoints of Judaism, Donatism and Apartism are highlighted to illucidate the central issue. In conclusion the writer attempts to expose the role and meaning that ecclesiology fulfils in this regard.
\end{abstract}

\section{Inleiding}

Pentecost is not a reversion to the unity of cultural uniformity; it is an advance towards the harmony of cultural diversity. We wish to affirm not only the unity of humanity but also the cultural diversity that ethnic groups bring to our societies (The Eucumenical Review; see Anon., 1995:226).

Ek begin hierdie artikel doelbewus met bogenoemde aanhaling omdat daar by my geen twyfel bestaan dat indien hierdie besluit, met sy balans tussen "unity" en "diversity", deur Afrikaanse kerke in Suid-Afrika in die jare 1948-1994 geneem sou gewees het, hulle van kerkapartheid verdink sou gewees het nie. Maar geneem in 'n totaal ander konteks (1994, Sri Lanka) en deur 'n konferensie van Christene geborg deur die World Alliance of Reformed Churches, die Lutheran World Federation en die World Council of Churches, klink bogenoemde aanhaling volledig aanvaarbaar. Waarom? Watter effek het wisselende kontekste en etniese verhoudings op Christen- en kerkwees? Hoe belangrik is kontekstualiteit en etnisiteit vir geloof, kerk en teologie? 
Die vraagstelling kan vanuit verskillende teologiese perspektiewe benader word: dogmaties beskou, roep dit die vraag na vore oor die verhouding tussen natuur en genade; eties benader, die vraag rondom situasie- of kontekstuele etiek; missiologies beskou, die vrae rondom akkulturasie en akkommodasie; ekklesiologies, die vrae rondom die eenheid van die kerk, volkskerk, liturgiese inkleding, ensovoorts.

In hierdie artikel gaan ons aan die hand van drie ondersoekvelde probeer aantoon watter bepalende en soms selfs deurslaggewende rol etnisiteit en kontekstualiteit in kerk en geloof gespeel het. Die teologiese vraag wat hiermee saamhang, is of dit altyd ten regte geskied het. Duidelik is dat dit onmoontlik is om los van 'n bepaalde konteks, dus konteksloos, teologie te beoefen, kerk te wees en geloof uit te leef. Ewe belangrik is natuurlik die vraag na die aard van daardie kontekstualiteit en of dit bepalend is vir geloof en kerk, soos by die kontekstualisme gebeur, én of dit wél 'n rol mag speel, maar dan nie 'n deurslaggewende rol nie (vgl. Van Genderen, 1993:110).

Die drie ondersoekvelde lê ver uit mekaar wat tyd en plek betref. Die eerste kom uit die Midde-Ooste en handel oor die verhouding tussen Joodse en heiden-Christene en raak ook die eenheid van die kerk. In hierdie verband word Handelinge 10 nader ondersoek.

Die tweede konteks is Noord-Afrika in (veral) die vierde en vyfde eeu en handel oor die verhouding tussen die Katolieke Kerk en die Donatistiese Kerk, waar onder andere die eenheid, katolisiteit en heiligheid van die kerk aan die orde kom.

Die derde konteks handel oor Suid-Arika waar die vraagstuk van apartheid die eenheid van die kerk en die versoeningsleer fundamenteel geraak het.

Die eerste veld van ondersoek is die gebeure in Handelinge 10.

\section{Judaïsme en die vroeë kerk}

Ten opsigte van die gebeure in Handelinge 10 is tereg opgemerk dat "this may be the veriest truism to us, but it was a revolutionary revelation to Peter" (Bruce, 1974:225). Die suigkrag van die Judaïsme (en Hellenisme) vir die Vroeë Kerk was immers baie groot (Joubert, 1991: 147).

Handelinge 10 handel oor die ontmoeting van die apostel Petrus met Kornelius, 'n kaptein in die Italiaanse regiment in Sesarea. Hierdie besondere gebeure sou die kerk en Christelike geloof onherroeplik op die pad van ekumenisiteit plaas, téén elke vorm van Judaïsme en 
sektarisme in. Dit is opvallend dat die Here juis die apostel Petrus uitkies om die evangelie aan Kornelius te bring. Die Here kon immers 'n engel of die evangelis Filippus gekies het. Filippus was trouens in Sesarea gevestig en het op daardie stadium reeds die evangelie aan 'n buitestander, die ontmande uit Afrika, gebring (Hand. 8:40, 21:8). Die Here het egter besluit dat dit Petrus moet wees wat hierdie groot oorgang en deurbraak moet maak. Vir Jode was dit destyds verbode om met onbesnedenes om te gaan en saam met hulle te eet (Hand. 10:28, 11:3).

Vanaf Joppe het Jona vir die heidensending weggevlug; vanaf Joppe word Petrus juis daartoe geroep. Wanneer Petrus die lakengesig sien en 'n stem hoor wat sê "slag en eet", dan reageer hy daarop met "nooit nie, Here!" Weldra sou die betekenis - en implikasies - van dié gesig vir Petrus duidelik word en sou hy die huis van Kornelius kon binnegaan met die woorde: "God het my gewys dat ek geen mens as onheilig en onrein mag beskou nie" (Hand. 10:28).

Nadat Kornelius aan Petrus vertel het van die engel wat aan hom verskyn en beveel het om Petrus te laat haal, reageer Petrus nog skerper as hy sê: "Waarlik ek begryp nou eers dat God nie onderskeid maak nie, maar uit enige volk die mense aanneem wat Hom vereer en doen wat reg is" (Hand. 10:34-35). God maak nie onderskeid nie, Hy diskrimineer nie (vgl. Jak. 2:1). As Hy Israel voorheen uitgekies het, dan word sy heilsplan nou, noudat Christus gekom het, verbreed, val die skeidsmuur weg en kies God uit alle volke vir Hom 'n nuwe volk (Calvijn, 1899:403; vgl. Harrison, 1975:172).

Die Griekse woord vir "onpartydigheid" (prosopolemptes) het 'n besondere betekenis. Dit is ook die enigste plek in die Nuwe Testament waar hierdie woord voorkom (Bruce, 1974:224). Dit het sowel 'n positiewe as negatiewe betekenis. Dié begrip hou verband met die Oosterse groetgewoonte waar iemand voor 'n ander kniel en die ander die gesig van die knielende persoon oplig as 'n gebaar van erkenning en waardering (vgl. Gen. 33:3-4; Est. 4:11) (Lohse, 1969:779). Dié begrip reflekteer die Hebreeuse nasa panim, wat beteken om "iemand se gesig op te lig", dit wil sê guns te bewys (Bruce, 1974:224; De Villiers, 1977: 222).

Naas hierdie positiewe het die begrip egter ook 'n negatiewe betekenis van partydige bevoorregting en boetiebegunstiging (favouritism), veral in die regspraak (vgl. Deut. 10:17; Lev. 19:15; Ps. 82:2; Spr. 18:5). Só oordeel God egter nié (Hand 10:34; Gal. 2:6; Ef. 6:9; 1 Pet 1:17) (Lohse 1969: 780) en daarom verwag Hy van sy gemeente ook dieselfde onpartydigheid (Jak. 2:1,9). God is nie partydig nie, Hy tel nie koppe om te sien of 'n persoon ' $n$ Jood is voordat Hy hom red nie. Nee, Hy red alle 
soorte mense, Hy neem mense aan "uit enige volk". Hy verlos sondaars (Rom. 5:8), Hy versoen vyande (Rom. 5:10), Hy regverdig goddelose (Rom. 3). "God does not look at a person's external appearance, nationality, wealth, social status and achievements" (Kistemaker, 1990:391).

Ons moet in hierdie opsig egter onderskei tussen die betekenisnuanses van "discriminate against" en "discriminate among". God diskrimineer teen niemand nie hoewel Hy tussen mense diskrimineer. Tereg merk Marshall (1989:189) op:

God does not have favourites. This means that, on the one hand, evid-doers cannot hope that he will show partiality to them at the judgement (Rom. 2:11; Eph. 6:9; Col. 3:25; 1 Pet. 1:17; Deut. 10:17), and, on the other hand, that no man need fear that God will not receive him out of partiality.

Polhill (1992:260) stel dit weer só:

Peter saw that God does not discriminate on the basis of race or ethnic background, looking up to some and down to others. But God does discriminate between those whose behavior is acceptable and those whose attitude is not acceptable.

Die genade is nooit goedkoop nie. Soos Calvyn (Inst, 3.16.1) iewers opgemerk het: "Thus it is clear how true it is that we are justified not without works yet not through works, since in our sharing in Christ, which justifies us, sanctification is just as much included as righteousness" (vgl. 3.4.3).

Dit sou ons te ver van ons onderwerp wegvoer om hier (in verband met God se nie-kieskeurigheid) breedvoerig aandag aan die uitverkiesingsleer te gee. Ons volstaan dus met die opmerking dat die uitverkiesingsleer geen demonstrasie is van God se partydigheid nie, maar juis van sy groot liefde en eindelose genade teenoor goddeloses en sondaars.

Petrus se uitspraak oor God se onpartydigheid ondermyn alle rassevooroordele in kerk (en samelewing) en onderstreep die noodsaak van kerklike ekumene (Rom. 3:29-30; Gal. 3:28; Ef. 2:14; Kol. 3:11). As Petrus hom voor die gemeente in Jerusalem oor sy ongewone optrede moet verantwoord - hulle het hom sy optrede erg verkwalik (Hand. 11:3) - dan aanvaar hulle sy verantwoording en prys die Here (Hand. 11:18).

Dat Petrus twaalf tot veertien jaar later blykbaar van hierdie gebeure vergeet het, strek hom tot oneer (Rackham, 1957:162). Dat hy later weer partydig was (Gal. 2), wys maar net hoe sterk die suigkrag van die sonde (van vooroordeel) is. Dat die kerk telkens weer in vooroordele, par- 
tydigheid en diskriminasie sou verval, is die skande van die kerkgeskiedenis.

Die gebeure van Handelinge 10 is inderdaad vir die kerk van fundamentele betekenis. Die evangelie is nie net vir Israel bedoel nie, maar vir "al die nasies" (Matt. 28:19), vir "die hele mensdom" (Mark. 16:15) en dit moet gehoor word "tot in die uithoeke van die wêreld" (Hand. 1:8). En wel só dat die vyandskap tussen Jood en nie-Jood in Christus opgehef word (Ef. 2:14) en die wilde lote in die mak Joodse olyfstam ingeënt word (Rom. 11: 17). "Christus is ons vrede" (Ef. 2:14) en daarom kan daar gepraat word van die "evangelie van vrede" en van "Jesus wat Here is van almal" (Hand.10:36). In die kerk van Christus is alle diskriminasie uitgesluit, alle partydigheid veroordeel, alle begunstiging verban; in sy kerk geld slegs eenheid, broederskap/susterskap en gemeenskap. Dis immers één kudde en één Herder (Joh. 10:16). In die kerk is daar net één liggaam, één Gees, één hoop, één Here, één geloof, één doop, één God en Vader (Ef. 4:4-6) (vgl. breedvoerig Van Wyk, 1990:6-30).

'n Oordrewe aksent op etnisiteit sou die Vroeë Kerk in 'n godsdienstige sekte laat ontaard het, terwyl God se heilsplan juis universeel aangelê is (vgl. 1 Tim. 4:10, 2:3-4). Die kerk is per definisie ekumenies of dit is geen kerk nie - hoogstens 'n kerklike sekte of 'n sektariese kerk.

\section{Donatisme in Noord-Afrika}

Die Donatistiese beweging in Noord-Afrika was nie sommer so 'n terloopse beweging wat maklik geïgnoreer en as 'n voetnoot in die kerkgeskiedenis gehanteer kan word nie. Dit was 'n beweging wat die kerk in Noord-Afrika diep verdeel het en vir ongeveer drie eeue (vierde tot sewende) sou duur. Aanvanklik was dit meer 'n etiese kwessie (ampsontrouheid aan Christus), maar weldra het dit ook 'n dogmatiese kleur gekry (en die eenheid van die kerk in gedrang gebring). Maar waarom het dit hoofsaaklik binne die konteks van Afrika en veral Numidië (vandag Oos-Algerië) afgespeel? "Why was it to be so different in Africa?" (Frend, 1952:22). Was daar dalk nasionalistiese ondertone in die Donatistiese beweging? Was dit 'n separatistiese beweging wat die vyandskap van die Berbers teen die Romeinse oorheersing uitgedruk het? (Frend, 1985: 71). Saamgevat: moet die Donatisme verstaan word as 'n beweging van Afrika-nasionalisme en kerklike separatisme? (Frend, 1952: xii).

In 1952 skryf Frend sy standaardwerk oor die Donatisme waarin hy bevind "that Donatism had been a movement of social and economic as much as religious protest" (Frend, 1985:73). Hy het veral gewys op die nie-teologiese aspekte onderliggend aan die Donatisme. "I tried to show 
the reasons for the outbreak in terms of a Berber and rural identity for Numidia in contrast to the more Romanised province of proconsular Africa where the African Catholics formed the majority" (Frend, 1985: 73).

Ons loop egter die verhaal vooruit. Laat ons voor begin en die vraag ondersoek hoe die Donatistieste Kerk ontstaan, ontwikkel en uiteindelik doodgeloop het 1 . Uiteraard sal net die relevante gegewens bespreek word.

Die ontstaan van die Donatisme hang saam met die groot Christenvervolging van 303-305 n.C. In 303 vaardig keiser Diocletianus 'n edik uit waarvolgens Christene hulle Bybels en die registrasiedokumente van kerkeiendomme moes inlewer, waarmee die verwoesting van kerkeiendomme geïmpliseer is (Frend, 1952:4). Hierop het sommige Christene die dokumente oorhandig (traditio, vandaar die naam traditores), terwyl ander (later navolgers van 'n beroemde biskop Donatus) geweier het. Toe dit bekend word dat Caecilianus as biskop van Kartago deur 'n traditor-biskop bevestig is, het 80 Numidiese biskoppe in die jaar 311 hierdie bevestiging ongeldig verklaar en iemand anders (Majorinus) in sy plek bevestig - 'n biskop wat in 313 deur Donatus opgevolg is (Frend, 1952:145-148; Brown, 1969:215). So ontstaan daar twee teenoormekaarstaande biskoppe in Kartago en spoedig oor die hele land, veral Numidië, waar die Donatiste die dominante kerk word - soos trouens ook in Hippo. Donatus is deur ongeveer 300 biskoppe erken (Frend, 1952:167). Hoewel daar ook Donatiste in Rome te vind was, het hulle oorsee gefaal, maar was in Afrika uiters suksesvol (Frend, 1952:164).

Van regeringskant (keiser Konstantyn) het die Donatisme groot vyandskap ondervind, iets wat nie net die breuk in die Afrika-kerk geïntensiveer het nie (Frend, 1952:159-160), maar ook die skeptisisme van die Donatiste teenoor "die wêreld", die vuil samelewing, verskerp het (Frend, 1952:165) - vandaar die voorkeur vir isolasie, soos ook by Tertullianus te vind is (Brown, 1969:222).

"In the last resort the differences between Donatist and Catholic turned on the relation between church and society, between Christianity and the

1 Vir kort oorsigte oor die Donatisme, vgl. Noordmans, 1933:171-193; Sizoo, 1957:230254; Brown, 1969:212-225; Frend, 1985:70-84; Van Oort, 1990:77-92; Van der Zwaag, 1993:70-79; Chadwick, 1996:75-86; Rist, 1999:239-245; Markus, 1999:284-287; Harrison, 2000:149-157.

Vir meer uitgebreide bronne, vgl. Frend, 1952; Willis, 1958; Tengström, 1964; Grasmück, 1964; Weijland, 1965. Die boek van E. Lamirande, La situation ecclésiologique des Donatistes d'aprés saint Augustin: Contribution á l'histoire doctrinale de l'oecum'enisme (Ottowa, 1972) word ook hoog aangeslaan. 
Roman Empire. The two communities provided contrary answers" (Frend, 1952:324). Uiteindelik is die ortodokse geloof deur die Donatiste gehaat vanweë hulle verbondenheid met die onderdrukkende staatsgesag (Frend, 1952:335).

In 340 kom 'n nuwe faktor by. Nou verskyn 'n nuwe groep op die toneel wat hulle sterk aangetrokke voel tot die Donatiste, naamlik die circumcellions (circum cellas $=$ rondom plattelandse huise/heiligdomme). Dit was veral boere van Bo-Numidië en Mauritanië, "religious fanatics, devoted to martyrdom" (Deo laudes) wat die landgoedere geterroriseer het (vgl. Frend, 1952:172-174; Sizoo, 1957:231; Fitzgerald, 1999:193194). By geleentheid het die circumcellions ' $n$ hinderlaag gestel om Augustinus te dood, maar hy het wonderbaarlik ontkom toe sy gids 'n verkeerde roete geneem het (Possidius, 1988:hfst. 12; vgl. Van der Zwaag, 1993:75; Chadwick, 1996:77-78). Van hulle het Augustinus die volgende te sê gehad: "They lived as robbers, died as circumcellions en were honoured as martyrs" (Frend, 1952: 75).

So het daar in Noord-Afrika twee kerkgroepe ontstaan, die Katolieke en die Donatiste, met weinig fundamentele teologiese verskille. Hulle het dieselfde Bybel gebruik, dieselfde geloofsbelydenis gehad, dieselfde liturgie, dieselfde sakramentsviering, dieselfde soort kerkgeboue (vgl. Frend, 1952:3, 239-240; Brown, 1969:217; Van Oort, 1990:78; Chadwick, 1996:76; Markus, 1999:286).

Die Donatisme is dus ' $n$ komplekse verskynsel. Teologiese en nieteologiese verskille het 'n rol gespeel (Frend, 1985:77; Markus, 1999: 285), en sosiale en etniese, maar ook ander verskille was aanwesig (Brown, 1969:217; Van Oort, 1990:217). Dit was in 'n sekere sin 'n konflik tussen ryk en arm, stad en platteland, Rome en Afrika (Markus, 1999:285). Soos Noordmans (1933:179) iewers opmerk: hier vind ons 'n vermenging van kerklike spiritualisme en politieke fanatisme (vgl. Frend, 1985:76-77).

Die vraag kan gestel word waarom Augustinus die Donatiste so teengestaan het en wat sy besware teen hulle was. Saamgevat kan Augustinus se kritiek in drie kategorieë verdeel word: hy het kritiek gehad teen die Donatiste se kerkbeskouing, ampsbeskouing en doopbeskouing.

\section{- Kerkbeskouing}

Wat die kerkbeskouing betref, het Augustinus volle klem laat val op die eenheid van die kerk, terwyl die Donatiste weer die heiligheid geaksentueer het (in navolging van Cyprianus). Die Donatiste het ook sterker klem gelê op die onderskeid tussen kerk en wêreld en het die 
kerk as alternatiewe samelewing gesien. Die traditores was volgens die Donatiste verraaiers, huigelaars en bang vir martelaarskap. Teenoor die partikularisme van die Donatiste het Augustinus die katolisiteit van die kerk gehandhaaf. Augustinus het geoordeel dat 'n mens tog moeilik die kerk net tot Afrika kon reduseer (Sizoo, 1957:240; Brown, 1969:221). Waar die Donatiste hulle vir die kerk as alternatiewe gemeenskap beywer het, het Augustinus die kerk as 'n corpus permixtum beskou (Van Oort, 1990:88-92).

Saam met die fokus op die eenheid van die kerk en daarmee saam die afwysing van enige skeuring, beklemtoon Augustinus die liefde as wese van die kerk (Van Oort, 1990:83, 85). Aan elke skisma lê (dikwels) broederhaat ten grondslag (vgl. Van der Zwaag, 1993: 74). Teenoor die nederige liefde van die kerk staan die hoogmoed van 'n skisma (Noordmans, 1933:187), want elke wegbreker beskou homself noodwendig beter en suiwerder as die ander. Daarom kan Augustinus (1992: 85) in 'n preek oor 1 Johannes 3 (6.2) die volgende opmerk: "Van die Donatiste byvoorbeeld kan 'n mens onmoontlik sê dat hulle die liefde besit, aangesien hulle die eenheid verskeur het". Tereg merk Noordmans (1933:191) op: "Als men den kerkvader vraagt waar de kerk is, dan zal hij niet antwoorden: daar waar de heiligheid is, maar: waar liefde woont. Daar vloeit de stroom van Gods genade."

\section{- Ampsbeskouing}

Die tweede verskil vloei uit die eerste voort, naamlik oor die ampsbeskouing. Die Donatiste het die geldigheid van die doop deur Katolieke biskoppe (traditores) ontken, asook die bevestiging van biskoppe deur Katolieke biskoppe waardeloos geag. Die Donatiste het dus die geldigheid van die sakramentsbediening en ampsuitoefening van die waardigheid van die ampsdraer afhanklik gemaak, maar Augustinus het geoordeel dat dit juis nié die geval is nie. Die werking van die sakramente (afwassing van die sonde) hang nie af van die heiligheid van die bedienaar nie, maar van Gód wat ter wille van Christus en deur sy Gees vergifnis skenk (Van Oort, 1990:78, 87-88).

\section{- Doopbeskouing}

Die derde verskil hang met die tweede saam, naamlik die doopbeskouing. Die Donatiste het nie die doop deur Katolieke biskoppe erken nie en kinders dus oorgedoop, iets wat Augustinus totaal afgekeur het hoewel ons moet byvoeg dat die Donatiste self die herdoop nie altyd as noodsaaklik beskou het nie (Frend, 1952:168). 
Opsommend kan gesê word dat Augustinus die Donatiste gekritiseer het vanweë hulle perfeksionisme, partikularisme, skismatisme, asketisme en rigorisme; saamgevat: hulle liefdeloosheid.

Oor Augustinus se optrede teenoor die Donatiste en die afloop van die beweging kan ons kort wees. Daar is onder navorsers konsensus dat Augustinus se hantering van die Donatiste-kontrovers nie teologies en eties verantwoord kan word nie (vgl. Noordmans, 1933:177; Frend, 1952:227-243). Natuurlik moet daar gewys word op Augustinus se eindelose geduld met die beweging en dat hy eers na tien jaar en na vele debatte, korrespondensie en boeke en na die groot Carthaagse konferensie van 411 oorgegaan het van die standpunt dat staatsdwang geoorloof is om Katolieke te beskerm, tot die standpunt dat Donatiste tot die Katolisisme gedwing behoort te word (Luk. 14:23) (Sizoo, 1957:242244; Rist, 1999:240, 243). Opvallend is dat Augustinus in sy $R e-$ tractationes 2.5 sê dat dit nie sy wens was om die skeurmakers (skismatici) met staatsgeweld te laat terugdwing nie (Frend, 1952:240).

In 405 het keiser Honorius die Donatiste as ketters (heretici) verklaar en was hulle dus verbode (Frend, 1952:263), maar eers in 412, na die groot Carthaagse konferensie van 411 , het die keiser die Donatisme verbied, is hulle biskoppe verban en Donatisme as kriminele oortreding verklaar. Die Donatiste sou egter op die platteland nog voortleef, selfs na die inval van die Vandale in die vyfde eeu, en wel tot in die sewende eeu toe die totale Christendom deur die Islam oorweldig is (Sizoo, 1957:254; Frend, 1952:315, 316). "Certain is that Donatus' work did not lead to the foundation of a permanent national Church on the lines of the Coptic Church in Egypt" (Frend, 1952:313). Frend (1952:313-314) wys op die ironie dat "the efficiency of the Catholics had the paradoxical result of being a factor in the permanent loss of north Africa to Christendom".

Dit is uit die voorgaande duidelik dat die verhouding geloof-etnisiteitkontekstualiteit ten tye van die Donatistiese kontrovers ' $n$ besondere rol gespeel het. Die Romeinse en Afrika-kulture en -kontekste het die geloof - of eerder die kerk - diepgaande beïnvloed. Augustinus het met alle mag tot sy beskikking - teologies en uiteindelik ook polities - die eenheid van die kerk verdedig, maar uiteindelik nie (volledig) in sy doel geslaag nie.

Die teologiese basis van die Donatistiese afskeidingsbeweging was te dun en die nie-teologiese faktore te sterk om tot 'n werklik lewensvatbare beweging uit te groei. Dit was 'n konflik tussen Afrika en "dit van wat oorsee kom", soos die Donatiste graag gesê het; 'n konflik tussen Afrikaekklesiologie en Rome-ekklesiologie, maar ook tussen die wyse waarop 
Afrika en Rome die verhouding tussen kerk en staat geformuleer het (Markus, 1999:286).

So gesien, was daar in die kerkstryd in Noord-Afrika geen wenner nie. Sou die kerk dalk die aanslag van die Islam oorleef het indien daar groter eenheid gewees het? Dit is 'n vraag wat seker nooit bevredigend beantwoord sal word nie, maar sy relevansie vir die kerk van die twintigste eeu - ook in Suider-Afrika - bly behou.

\section{Apartisme in Suid-Afrika ${ }^{2}$}

Die geskiedenis van die Suid-Afrikaanse apartisme is so algemeen bekend dat die woord apartheid - byna soos die woorde Coca Cola en Halleluja - wêreldwyd bekend geword het. Dat etnisiteit en kontekstualiteit ten opsigte van geloof, kerk en teologie in Suid-Afrika ' $n$ besondere groot rol gespeel het, is oorbekend. "Christianity, as the dominant religion in South Africa, promoted the ideology of apartheid in a range of different ways" (TRCSA, 1998:91). Die prikkelende aspek is egter hoe dit moontlik kon wees dat gereformeerde kerke, in besonder die GKSA, wat so uitgesproke teen 'n volksteologie en volkskerk gekant was, in die maalkolk van 'n apartheidsideologie ingesuig kon word enkele uitsonderings daargelaat. Hoe is dit moontlik dat (byvoorbeeld) leidinggewende teoloë soos J.D. du Toit (1877-1953), W.J. Snyman (1899-1981) en 'n filosoof soos H.G. Stoker (1899-1993) 'n apartheidspolitiek in 'n mindere of meerdere mate kon ondersteun het?

Uiteraard kan in hierdie konteks slegs kortliks op hulle standpunte ingegaan word.

\section{- H.G. Stoker}

Stoker (1899-1993) het 'n enorme bydrae gemaak ten opsigte van die uitbou van 'n Christelike filosofie en wetenskapsbeoefening in SuidAfrika. Tog kon hy hom nie in sy politieke filosofie van die apartheidsideologie losmaak nie (vgl. breedvoerig Van Wyk, 1993:49-50, 1994: 435-454). Vir Stoker (1941:157) is dit duidelik dat "ons segregasiebeleid op 'n Calvinistiese rasseleer rus". Apartheid is 'n beginsel van ons lewens- en wêreldbeskouing, ons saak is reg. Ons 'volksideologie' is wesentlik Calvinisties" (Stoker, 1967:329).

Die vraag ontstaan: sou die feit dat Stoker hom oor 'n lang tyd met die vryheidstryd van die Afrikaners na die Tweede Anglo-Boereoorlog (1899-

2 Aangesien daar reeds in baie bronne aandag bestee is aan die NGK en apartheid (vgl. bronverwysings by Van Wyk, 1993:39), gaan ek in hierdie onderafdeling toespits op apartheid en die GKSA. 
1902) geïdentifiseer het, dat hy as kommandant van die OssewaBrandwag tydens die Tweede Wêreldoorlog (1939-1945) geïnterneer was, dat hy die Christelik-Nasionale Onderwys-beweging sterk ondersteun het, 'n bepalende rol gespeel het in sy politieke filsosofie? Het sy verbondheid aan 'n bepaalde volk, binne 'n bepaalde konteks, sy denke sodanig gekleur dat hy nie 'n politieke ideaal (Afrikanervolksvryheid) van 'n politieke ideologie (apartheid as Afrikanerimperialisme) kon onderskei nie? Meer algemeen gestel: wat vrywaar enigiemand van ideologiese suigkrag?

\section{- J.D. du Toit}

Hoewel J.D. du Toit (1877-1953) vanweë sy aandeel aan die Afrikaanse Bybelvertaling, Psalmberyming en poësie ' $n$ besondere bydrae tot die Afrikaanse kerk- en kultuurgeskiedenis gelewer het, was sy bydrae tot die uitbou van die reformatoriese teologie beperk. Wat sy politieke etiek betref, het hy volledig binne die apartheidsparadigma gestaan (vgl. Van Wyk, 1993:41-43) - hoewel hierdie uitspraak deur ander bevraagteken word (D'Assonville, 1993:270). Sy voordrag voor 'n volkskongres in Bloemfontein in 1944, wat gehandel het oor "Die godsdienstige grondslag van ons rassebeleid" lewer onteenseglik bewys daarvan dat Du Toit 'n voorstander van rasseskeiding was (Du Toit, 1977:330-343). Volgens Du Toit is God die groot Skeidingmaker, soos reeds by die skepping gesien kan word, asook by Babel en Israel. Dit is wel waar dat Christus 'n eenheid gebring het, maar dis 'n "hoëre eenheid" en ook "geestelik van aard". Die Christendom wis nie verskille uit nie, maar heilig dit stellings waaruit ook Du Toit se siening van die verhouding natuurgenade duidelik word.

Dit is waar dat Du Toit nie die hoogbloei van apartheid (vanaf 1960) meegemaak het en dus nie die wrange vrugte daarvan ervaar het nie, maar dis duidelik dat hy reeds voor 1948 tot met sy dood in 1953 aan die die beginsel van skeiding en voogdyskap vasgehou het (Du Toit \& Du Toit, 1955:3).

Ook ten opsigte van Du Toit moet die vraag gestel word watter rol sy ervarings tydens die Tweede Anglo-Boereoorlog en sy stryd vir Afrikanerskap (D'Assonville, 1977:105-111) in sy teologie en kerk- en staatsbeskouings gespeel het. (Daar moet in gedagte gehou word dat Du Toit vir nege maande [1899-1900] in die Tweede Anglo-Boereoorlog betrokke was [D'Assonville, 1977:22-32].) Deesdae word hierdie verhouding oor die algemeen as "kritiese solidariteit" beskryf, maar die vraag ontstaan, en dit geld vir élke teoloog in élke konteks, of die solidariteit (mét die eie kultuur) nie die kritiek (téén die eie kultuur) minimaliseer en soms selfs nivilleer nie. 


\section{- W.J. Snyman}

Meer as enigiemand anders van sy eie tyd het W.J. Snyman (18991981) myns insiens probeer om weg te beweeg van die apartheismodel, veral op kerklike gebied, hoewel tog gekonkludeer moet word dat hy nie volledig daarin geslaag het nie (vgl. Van Wyk, 1985, 1993:45-48). Hy het baie sterk met die natuur-genademodel gewerk en dit só gestel: in die kerk word die sondige teenstellings opgehef, maar nie die natuurlike onderskeidings nie (Snyman, 1977:285, 312). Daarom kon hy hom daarvoor beywer dat uit die vier nasionale sinodes van die Gereformeerde Kerke in Suidelike Afrika (wit, bruin en twee swart) één algemene sinode saamgestel word (Snyman, 1977:85)(vgl. ook Coetzee, 1965:317-321) 'n sinode wat sedert 1965 inderdaad vir 'n aantal jare vergader het. Die vraag is egter: lê aan die begrip "nasionale" sinode nie reeds 'n volkskerkbegrip ten grondslag nie, veral in sy Suid-Afrikaanse konteks? - iets wat Snyman juis skerp afgewys het. Ongelukkig het Snyman myns insiens "volk" en "land" so nou op mekaar betrek dat die moontlikheid van meer volke (as een nasie) in dieselfde land bevraagteken is (Snyman, 1977:322). Tog het sy beklemtoning van die koninkryk van God as omvattende teologiese paradigma - in aansluiting by H.N. Ridderbos - 'n bevrydende verruiming vir die ekklesiologie teweeggebring. Wie die kerk binne die wye ruimte van die koninkryk benader, word bevry van 'n bedompige kerklike introvertisme.

Ek het herhaaldelik die vraag gestel hoe dit moontlik kon wees dat kerke en teoloë nie gou genoeg die dwaling van apartheid kon insien en weerspreek nie (vir besluite van die GKSA, vgl. Van Wyk, 1993:51-55). Hoe kon dit alles gebeur het? (vgl. Van Wyk, 1998:196-199).

Dat daar, ook vanuit die GKSA, kritiek teen apartheid uitgespreek is, is waar (vgl. Van Wyk, 1993:39-60; Van der Walt, 1993:29-52; 1994:375399; 1995:26-36; De Klerk, 2000:28-43). Maar was dit nie té min té laat nie?

Wat het veroorsaak dat apartheid ook binne die Gereformeerde tradisie sonder veel teenstand kon ontwikkel? Hang dit saam met piëtisme, NeoCalvinisme en romantisisme? (vgl. Van Wyk, 1993:39-40).

Ek gaan in hierdie verband enkele teologiese en politieke faktore wat in hierdie verband 'n rol gespeel het, kortliks uitlig en bespreek.

\section{- Apartheid as gevolg van 'n fundamentalistiese Skrifbeskouing?}

Eerstens die vraag: moet apartheid aan 'n fundamentalistiese Skrifbeskouing gewyt word? Gerrie Snyman het hierdie belangrike vraag gestel: "As bely word dat apartheid verkeerd is, hoe kan die histories- 
letterlike [naïef-realistiese] benadering [van die Bybel] nog gehandhaaf word?" (Beeld, 10-10-1997) (vierkanthakies van my). Carroll (2000:3953) gaan in sy kritiek selfs so ver as om te beweer dat "the Bible is an unsafe book from which to do politics or social engineering in contemporary society" (Carroll, 2000:51). Die Bybel bied syns insiens sowel bevrydende as onderdrukkende modelle en moet dus uiters krities gelees word.

Natuurlik is dit waar dat die voorstanders van apartheid 'n teks soos Handelinge 17:26 (en Gen. 11:1-9; Op. 21:3) maklik op 'n fundamentalistiese wyse kon verstaan en apartheid op grond daarvan kon regverdig. Fundamentalisme kon dus 'n rol gespeel het, maar dit was nie 'n alleenfaktor nie. Globaal gesien, was daar in Suid-Afrika kritiese teoloë wat politiek-konserwatief gedink het (vgl. die NHKA), terwyl daar konserwatiewe teoloë was wat politiek-krities gedink het (vgl. W.D. Jonker) (vgl. Van Wyk, 1999:219-220).

Dit kan nie ontken word dat 'n verkeerde Skrifbeskouing (fundamentalisties of kritisisties) en 'n daaruit voortvloeiende Skrifverklaring inderdaad 'n negatiewe rol ten opsigte van sosiale vraagstukke kan speel nie.

\section{- Teologiese verblinding}

Tweedens sou apartheid toegeskryf kon word aan teologiese verblinding. Politieke voorveronderstellings en selfs vooroordele veroorsaak dat die Bybel deur ' $n$ bepaalde politieke bril gelees word as gevolg waarvan belangrike teologiese temas, soos byvoorbeeld versoening en die eenheid in Christus, nie behoorlik, of glad nie, verreken word nie. Daarom was die besluit van die GKSA in 1991 so belangrik toe gestel is dat "die ideologie van apartheid 'n sonde en die teologiese regverdiging daarvan 'n dwaling is " (Acta GKSA, 1991:160, 169).

\section{- Die volkskerkgedagte}

Derdens moet opgemerk word dat die volkskerkgedagte, hoewel dit deur die GKSA afgewys is, tog ondergronds 'n rol gespeel het. Hoewel Snyman, soos ons reeds opgemerk het, 'n volkskerk afgewys het, het hy tog in aansluiting by standpunte van Grosheide en Stauffer, vir die model van 'n volkerekerk gekies (vgl. Van Wyk, 1985:14-16). Dit het ingehou dat in elke volk eie taalgemeentes asook eie kerkvergaderings tot op nasionale vlak ontwikkel. Uit die verskillende nasionale sinodes is dan 'n algemene sinode oor taal- en kultuurgrense heen saamgeroep. Die teologiese besware lê voor die hand: die kerk volg in 'n groot mate 'n politieke model van aparte volke, terwyl kontak tussen gelowiges in die plaaslike gemeentes onderbeklemtoon en in sommige gevalle selfs ontken is. 


\section{- A. Kuyper se Neo-Calvinisme}

Vierdens is beweer dat die apartheidsideologie beïnvloed is deur die Neo-Calvinisme van A. Kuyper, wat baie positief oor die Boere en minder vleiend oor die Afrikane geskryf het. Navorsing het egter aangetoon dat daar meningsverskil oor die standpunt van Kuyper in hierdie verband bestaan. Enersyds word daar gewys op Kuyper se positiewe oordeel oor bloedvermenging en sy afwysing van die volkskerkgedagte (vgl. Van Wyk, 1993:55), terwyl andersyds tog van 'n oorsaaklike invloed op apartheid sprake is (Van der Kooi \& De Bruijn, 1999; vgl. ook McGoldrick, 2000). Kuyper se ekklesiologie het egter geen ruimte gelaat vir die profetiese getuienis van die kerk-as-instituut in die samelewing nie, 'n aspek wat, gesien die besondere Suid-Afrikaanse konteks, die kerk groot skade berokken het.

\section{- Kontekstuele teologie het ontbreek}

Vyfdens kan aangevoer word dat daar in Suid-Afrika oor die algemeen 'n gebrek was aan 'n verantwoordelike kontekstuele teologie. Geen teologie word immers in 'n vakuum beoefen nie, en behoort, as relevante teologie, noukeurig op hoogte te wees met die sosio-ekonomiese konteks waarin dit beoefen word. Dit beteken nie dat die konteks die teologie normeer nie, maar wel dat die konteks in die teologiese beoefening verreken behoort te word (Van Wyk, 1995:259-261, met bronverwysings; vgl.Russell, 1995). Tydens die apartheidsjare is die politieke konteks van dominasie en diskriminasie nie genoegsaam verreken in die teologiebeoefening in Suid-Afrika nie - soos wat die konteks van armoede, werkloosheid, vigs, misdaad en ekologiese versteuring tans nie genoegsaam in ag geneem word nie.

\section{- Verabsolutering van die volksgedagte}

Sesdens kan verwys word na die verabsolutering van die volksgedagte (etnosentrisme/nasionalisme) - iets wat weer nou saamhang met rassisme. Die byna vernietiging van die Afrikanervolk deur die Britse imperialisme tydens die Tweede Anglo-Boereoorlog (1899-1902) het die kiem gelê vir 'n sterk volksbewussyn en ongekende vryheidstrewe by die Afrikaners - byna soos wat die vrede van Versailles in 1919 die kiem vir die Tweede Wêreldoorlog bevat het. Groot klem is deur Afrikaners gelê op motiewe soos (volks-)verskeidenheid, vryheid en roeping, en dit alles is nou verbind aan die voorsienige bestel van God. In die uitwerking van die ideaal van volksvryheid en in die ontwikkeling van die apartheidsideologie is die Afrikanervolk egter verabsoluteer, tot groot skade en skande van ander Suid-Afrikaanse burgers en volke. 


\section{- Politieke idealisme ontaard in politieke ideologie}

In die sewende plek kan vermeld word dat 'n politieke idealisme tot politieke ideologie ontaard het, wat op sy beurt weer tot politieke verblinding aanleiding gegee het. Daar bestaan geen politieke party, geen volk of nasie sonder bepaalde ideale nie, maar wanneer ' $n$ ideaal tot ideologie ontspoor, wanneer 'n ideaal ten koste van ander gehandhaaf word, dan word dit 'n monster wat 'n samelewings ondermyn en uiteindelik kan vernietig. Hierdie ideologisme is nie tipies van die Afrikaners nie, maar is ook te vind in Britse imperialisme, Nederlandse kolonialisme, Duitse nasionaal-sosialisme, Russiese kommunisme, Amerikaanse neokolonialisme en in Afrika-diktature (vgl. Stott, 1990:215-221).

Die vraag ontstaan of daar hoegenaamd 'n uitweg uit hierdie teologiese labirint gevind kan word. Watter basisprinsipes is nodig om 'n juiste verhouding tussen geloof, etnisiteit en konteksutalieit te formuleer?

Etnisiteit en kontekstualiteit verdien 'n plek in die geloofsgemeenskap en kerkwees, maar wanneer dit oorbeklemtoon word, word dit faktore wat geloofsondermynend en kerkverwoestend werk.

\section{Perspektiewe vanuit die ekklesiologie}

Daar bestaan geen eenduidige antwoord op 'n komplekse vraagstelling nie. Vir 'n antwoord op die verhouding geloof-etnisiteit-kontekstualiteit sal verskillende teologiese insigte 'n rol speel, byvoorbeeld die Skrifbeskouing, Skrifverklaring, hermeneutiek, insig in die (sosiale) konteks, die wyse waarop die Skrif op die konteks betrek word, ensovoorts. In hierdie benadering word slegs op 'n enkele belangrike aspek gefokus, naamlik op die rol en betekenis van die ekklesiologie (vgl. onder andere Küng, 1967; Berkouwer, 1970,1 972; Moltmann, 1975; Van't Spijker et al., 1990).

\subsection{Die kerk as genade-instituut}

Die vraag na die verhouding tussen geloof en etnisiteit is ten diepste 'n vraag na die verhouding tussen natuur en genade, 'n saak wat ten grondslag lê aan die problematiek van die Suid-Afrikaanse samelewing (vgl. Van Wyk, 1991:347-348; 1993:46). Deist (1994:180-188) het aangetoon hoedat hierdie begrippe op 'n naïewe en foutiewe wyse in die Suid-Afrikaanse teologiese en politieke debat misbruik is. Herhaaldelik is van die Thomistiese formulering gebruik gemaak: gratia non tollit naturam, sed perficit - hoewel Bavinck die "voltooi" na "herstel" verander het 
(vgl. Theron, 1988:16). Oor hierdie tema ${ }^{3}$ is reeds veel besin sodat hier slegs op enkele relevante aspekte ingegaan word.

Met hierdie onderwerp is in 'n bepaalde sin ook die verhouding tussen Christus en kultuur aan die orde gestel, 'n tema waaroor onder andere Schilder (1948) en Niebuhr (1956) so indringend geskryf het.

Dit is bekend dat Niebuhr ten minste vyf verhoudings tussen Christus en kultuur onderskei het, waarvan hier, met bepaalde aanpassings, gebruik gemaak gaan word (vgl. Van der Walt, 1994:99-109).

- Die genade isoleer (die genade staan buite die natuur). In hierdie benadering onttrek die gelowige hom aan die sosiale lewe en leef eenkant in isolasie. Vergelyk in hierdie opsig die Essene, die Donatiste en bepaalde vorme van die Anabaptisme, piëtisme en sektarisme.

- Die genade opponeer (die genade staan teenoor die natuur). Hier is dit nie 'n geval van isolasie nie, maar van duidelike teenkanting teen die sosiale lewe. Vergelyk in hierdie opsig die standpunt van Tertullianus en die Jehovagetuies.

- Die genade akkommodeer (die genade bestaan saam met die natuur). Genade en natuur, geloof/kerk en volk val haas ononderskeibaar saam. Vergelyk in hierdie opsig die standpunte van Eusebius, die Social Gospel, Ritschl en bepaalde vorme van die Bevrydingsteologie.

- Die genade komplementeer (die genade staan bo die natuur). Die genade dien as middel om die natuur te voltooi en te vervolmaak. Vergelyk in hierdie opsig Thomas van Aquino en die Katolieke Kerk.

- Die genade dualiseer (die genade bestaan langs die natuur). Die verhouding genade-natuur word paradoksaal geformuleer en wel so dat kerk en volk/staat langs mekaar gedink word. Vergelyk in hierdie verband Luther en Troeltsch.

- Die genade transformeer (die genade werk transformerend in op die natuur). Die genade word beskryf as 'n veranderende krag in die samelewing. Vergelyk in hierdie opsig Augustinus en Calvyn.

- Die genade infiltreer (die genade werk helend in op die natuur) Die genade word gedefinieer as 'n beïnvloedende krag in persone en samelewings - soos sout, suurdeeg en lig. Hierdie benadering stem grotendeels met die vorige ooreen, behalwe dat in hierdie geval die

3 Vgl. inleidend Van Ruler, 1969:121-133; Wentsel, 1970; Noordmans, 1986:428-451; Smit, 1987:115-142; Theron, 1988:157-171; Veenhof, 1994. 
mag van die sonde sterker verreken en minder optimisties oor die "transformasie van samelewings/kontinente/wêreld" gedink word.

In Nederland het veral Schilder, naas Kuyper, die tema van Christus en kultuur onder die soeklig geplaas. Douma (1990:169-201) bied hiervan 'n goeie oorsig, asook van die kritiek wat daar teen Schilder se benadering, waarin die antitese 'n sterk rol speel, ingebring is (van Miskotte, Noordmans, Van Ruler, Velema en Douma self). Douma ag dit belangrik dat Christus met die kultuur verbind word, maar dan moet dit met álle (dit wil sê ook nie-Christelike) kulture gebeur. Daarby mag dan ook nooit vergeet word dat die Christen as kultuurbouer altyd vreemdeling op aarde is nie (Douma, 1990:195). Tereg merk Veldhuizen (1995:91, 95) op: "Wij zien het als een idealistische trek van Schilder om religie en cultuur te vereenzelvigen" en "... in Schilders zienswijze worden religie en cultuur te weinig onderscheiden en te zeer vereenzelwigd".

Só beskou, sou Schilder ingedeel kon word by die siening dat die genade akkommodeer kon word, maar sy standpunt bevat te veel nuanses om dit op simplistiese wyse te doen. Dit is egter duidelik dat Schilder diepgaande deur sy Nederlandse en Europese konteks beïnvloed is. Anders gestel: hoeveel waarde het Schilder se siening vir die plurale Afrika-konteks?

Dit is bekend dat die begrip kultuurmandaat in Schilder se siening 'n belangrike plek inneem. Hoewel hy in hierdie verband moedige ondersteuners het (Gootjes, 1995:35-64), bly 'n aantal vrae myns insiens nog onvoldoende beantwoord: word die begrip kultuurmandaat nie te onchristologies en te veel buite die sendingopdrag om hanteer nie? Verreken dit die (gevolge van die) sondeval genoegsaam? Word die héérsmotief nie ten koste van die bewáármotief beklemtoon nie? Word die eskatologie hierin genoegsaam verreken?

Om terug te keer na die sesde model, naamlik dat die genade transformeer: is die algemeen gangbare begrip van transformasie, veral waar dit gaan oor die transformasie van samelewings en kontinente, nie te hoog gemik nie? Dat die evangelie/ genade 'n individuele persoon kan transformeer - al bly dit altyd nog 'n verloste sóndaar - is duidelik; dat dit 'n huisgesin kan transformeer, dat daar Christelike skole en universiteite kan ontstaan, is alles moontlik. Maar die transformasie van sámelewings, in die volle sin van die woord? Dit bly 'n ope vraag. 'n Samelewing bestaan immers uit gelowiges, bygelowiges en ongelowiges en kan alleen met staatsgeweld "verchristelik" word - iets wat ingaan teen die wese van die evangelie as 'n evangelie van vrede wat op oortuiging (sonder dwang) gebaseer is. Nêrens ter wêreld is ooit daarin geslaag om samelewings volhoubaar te transformeer, in die sin van te verchristelik 
nie. Dat die Christendom veel beteken het vir humanisering en demokratisering is ongetwyfeld waar, maar daarteenoor staan dat twee vernietigende wêreldoorloë juis deur hoofsaaklik "Christelike" nasies ontketen is (vgl. Thom, 2000:50-68).

Wat die evangelie/genade/geloof wél kan doen, is om samelewings en samelewingstrukture ten goede te beïnvloed en 'n nuwe norm- en waardesisteem te help vestig. Alhoewel ek die motief agter die transformasiegedagte as geldig erken, is ek huiwerig om dit ongekwalifiseerd op 'n plurale samelewing van toepassing te maak. Dit hou ook nie genoegsaam rekening met die weerbarstigheid van die sonde nie.

Uiteindelik is nét die kérk genade-instituut op aarde.

\subsection{Die kerk as eenheids-organisme}

Dat die temas van etnisiteit en kontekstualiteit baie maklik ten koste van die eenheid van die kerk beklemtoon kan word, is uit die kerkgeskiedenis baie duidelik - soos aangetoon. In hierdie verband moet die volkskerkgedagte, in die betekenis van "kerk van die volk" as dodelike vyand aangeteken word.

Die Nuwe Testament is te duidelik oor die eenheid van die kerk (Ef. 4:46) en nêrens is daar selfs ' $n$ suggestie dat 'n kerkskeuring mag of behoort plaas te vind nie, wat nog te sê van die bestaan van aparte volkskerke. Daar was groot sosiale, kulturele en geslagsverskille in die gemeentes in Klein-Asië, Griekeland en Palestina, ja, daar was selfs groot etiese en dogmatiese verskille wat die apostels moes hanteer, maar nêrens is daar selfs die geringste aanduiding van kerkskeuring (soos ons dit vandag ken) nie. Hierin was Augustinus korrek: die Heilige Skrif weet nie van 'n onenige, verdeelde en onkatolieke kerk nie (vgl. Breytenbach, 1987). Hiermee is nie gesê dat die waarheid aan die eenheid opgeoffer moet word nie, maar wel dat die eenheid (en katolisiteit) net so 'n waarheid as die heiligheid en apostolisiteit is. 'n Onenige kerk is per definisie 'n onwaarheid en 'n contradictio in terminis. 4

$4 \quad$ Dat daar in Suid-Afrika teen die einde van die twintigste eeu nog 'n kerkgemeenskap "net vir blanke Afrikaners" kon ontstaan, moet as 'n anachronisme aangemerk word (vgl. die Afrikaanse Protestantse Kerk, 1987). Die Nederduitsch Hervormde Kerk van Afrika het in 1997 'n belangrike stap vorentoe geneem deur die veel omstrede artikel 3 ("die kerk ... wil geen gelykstelling [tussen blank en nie-blank] in sy midde toelaat nie") te skrap. Die vraag is egter of met die nuwe ordereël 4 nie weer verloor word wat met die verval van artikel 3 gewen is nie: "Die kerk is 'n volkskerk met sy eie kerklike kultuur, geskiedenis, taal en tradisie wat geroepe is tot die verkondiging van die evangelie van Jesus Christus aan die Afrikanervolk en tegelyk aan alle mense" (Oberholzer, 1999:457). 
As gekyk word na die verskeurdheid tussen Oosterse en Westerse kerke, om van die eindelose verskeurdheid in die Westerse kerk maar te swyg, is dit 'n ope vraag of hierdie uitspraak nie oordrewe en idealisties is nie. Hierop sou ek wou antwoord dat onderskei moet word tussen die prinsipe/ideaal van eenheid enersyds en die praktyk/werklikheid van verdeeldheid andersyds en dat altyd daarvoor gebid en daarna gestreef behoort te word dat die ideaal ook inderdaad werklikheid word.

Eenheid beteken natuurlik nie eendersheid nie. Binne die raamwerk van die eenheid behoort daar ruimte te wees vir verskeidenheid in byvoorbeeld die liturgie. Hier kan gedink word aan die volgende besluit van die Gereformeerde Ekumeniese Sinode 1976, wat die GKSA ook sy eie gemaak het:

\begin{abstract}
The unity of the church as the body of Christ must be acknowledged. It may be that linguistic or cultural differences make the formation of separate congregations, often with their own type of preaching and worship, advisable and, in these cases it is wise not to force an outward and therefore artificial form of unity, but to recognise the differentiation within the circle of God's people. Where different churches for different indigenous groups exist, no person may be excluded from common worship on grounds of race or colour. Common worship, including the Lord's Supper, among Christians regardless of race is an expression of the unity of the body of Christ. Such worshipping together of people of different races, is a sign of the unity of the Church and the communion of the Saints and can be a Christian witness to the world (Acta GKSA, 1985:435, 437).
\end{abstract}

Dit is insiggewend dat daar tans wêreldwyd ' $n$ interessante debat plaasvind - 'n bewys van watter invloed konteksverskuiwings kan veroorsaak. In 'n wêreld wat deur groot (selfs gedwonge) verdelings gekenmerk is, is groot klem gelê op die eenheid van die kerk, terwyl daar tans, in 'n konteks van byna gedwonge eenheid, meer ruimte kom vir 'n gesprek oor verskeidenheid - vergelyk ook die aanhaling wat ons in die inleiding gestel het. Wêreldwyd vind tans 'n herwaardering plaas van die plek en betekenis van minderhede en verskeidenhede. Teologies gesien, behoort dit geen probleem te lewer nie, solank dit 'n verskeidenheid in die eenheid is en nie 'n verskeidenheid ten koste van die eenheid nie. Die kerk bely die eenheid en nie die verskeidenheid nie.

\title{
5.3 Die kerk as versoeningsinstrument
}

Dat die kerk van Christus, in enige konteks en onder alle kulture, 'n versoeningsinstrument sonder weerga is - of liewer: behoort te wees - is uit die Skrifopenbaring sonder meer duidelik. Uit die versoening met God deur Jesus Christus ( Rom. 5:10; 2 Kor. 5:11-21) vloei die versoening 
van Jood met nie-Jood (Ef. 2:14), en van alle nie-Jode met mekaar (Gal. 3:28), logies voort. Wie onversoend lewe met sy broer en suster wat in Christus glo, kan onmoontlik met God versoen lewe. Van so iemand word verwag om sy gawe by die altaar te los en om hom eers met sy broer/suster te gaan versoen voordat hy/sy sy/haar offer bring (Matt. 5:23-24).

Elke vorm van kerklike en geloofsapartheid is volledig in stryd - nie net met die belydenis van die eenheid van die kerk nie - maar ook met die belydenis van die versoening as genadedaad van God. In watter konteks iemand ook al leef, aan watter volk hy ook al behoort, wie in Christus glo, is met God en ook met mekaar versoen en is deel van die een liggaam van Christus. Geloofsgenote staan nader aan mekaar as volksgenote en selfs as bloedgenote (Matt. 12:50).

Die versoening met die broer en suster tree veral duidelik aan die lig tydens die versoeningsmaaltyd, die Maaltyd van die Here. Wie weier om met sy broer of suster uit 'n ander volk of kultuur Nagmaal te vier, weier die versoening met God.

Die realisering van versoening in die kerk demonstreer ook die eksemplariese bestaan van die kerk in die wêreld. In 'n wêreld wat dikwels gekenmerk word deur verdeeldheid, onenigheid en vyanskap, behoort die kerk uit te staan as ligbaken van vrede, vriendskap en versoening. Die versoening het inderdaad ook kosmiese betekenis wat die hele samelewing raak. Die spreek natuurlik vanself dat die versoening in die kerk as geloofsgemeenskap 'n veel dieper en ryker betekenis sal hê as versoening in die samelewing waar gelowiges en ongelowiges vermeng saamlewe. Maar in die samelewing behoort ook iets van die vrede met Christus neerslag te vind (Rom. 12:18) (vgl. Van Wyk, 1999:216-217, met bronverwysings).

Dit is 'n harde stelling om te maak, maar tog moet dit gemaak word: Vanweë die ondersteuning van of betrokkenheid by apartheid in SuidAfrika - aparte gemeentes, aparte eredienste, aparte Nagmaalsvierings en aparte kerkvergaderings - het die Afrikaanse kerke in Suid-Afrika in 'n groot mate gefaal om instrumente van versoening te wees. Juis hierdie mislukking van die verlede maak die uitdaging vir die toekoms soveel groter.

\subsection{Die kerk as liefdesgemeenskap}

Ons het by Augustinus gesien dat die kerk vir hom voor alles 'n liefdesgemeenskap is en dat juis dít een van die redes was waarom hy hom so teen die Donatiste verset het. Dit is stellig nie oordrewe om te sê 
dat in die ekklesiologiese ontwerpe en belydenisse die tema van liefde 'n baie ondergeskikte posisie inneem nie. Dit verskyn nie in die Christelike belydenis as een van die eienskappe van die kerk nie en ook nie as een van die kenmerke van die ware kerk nie. Dit figureer ook nie juis by die soeke na eenheid tussen (ook gereformeerde) kerke nie.

Trouens, in die gereformeerde tradisie word die kriteria van eenheid in leer, diens en tug gewoonlik aangelê. Tog is dit opvallend dat ons reeds by Calvyn (Inst. 4.2.5), in aansluiting by Augustinus, nie drié nie, maar twéé kriteria aantref, as hy opmerk: "Now this communion is held together by two bonds, agreement in sound doctrine and brotherly love." Dwaalleraars (heretici) verbreek die eenheid deur valse dogmas en skeurmakers (skismatici) deur afsydigheid.

Liefde - dit is die hoofkenmerk van die Christen en die Christelike kerk. Liefde is "die grootste" van al God se genadegawes (1 Kor. 13:13), dit is die "neerslag" van die wet en die profete (Matt. 7:12), dit is die "volle uitvoering van die wet" (Rom. 13:10), die "samevatting van die hele wet" (Gal. 5:14), ja, die "wet van die koninkryk van God" (Jak. 2:8).

Daarom kan van 'n kerk gesê word dat, al is dit ook hoé suiwer in die leer (Op. 2:2-3), maar waar die liefde ontbreek (Op. 2:4), dit van sy staanplek verwyder sal word - tensy daardie kerk hom grondig bekeer (metanoia!) (Op. 2:5).

Daarom ook dat die kerk van Efese, ja, alle kerke van alle tye, die opdrag ontvang om in liefde by die waarheid te bly (Ef. 4:15).

\section{Voorlopige konklusie}

Oorsien ons die afgelegde weg, dan blyk duidelik dat daar tussen geloof, etnisiteit en kontekstualiteit 'n duidelike relasie aanwesig is. Dit is so dat geloof 'n invloed uitoefen op volk en konteks, maar die omgekeerde is ook waar dat die geloof - geloofsbelydenis en geloofsbelewing - op sy beurt deur etnisiteit en konteks gekleur word. Die oplossing van die verhouding moet gesoek word in die rigting waar enersyds die essensie van die geloof en kerkwees ongeskonde behoue bly, maar andersyds die bepaalde konteks waarin dit gestalte aanneem, volledig verreken word. So sal die eenheid van die geloof en kerkwees ongeskonde bewaar bly, terwyl die sonde van onenigheid en die verveeldheid van eendersheid vermy word.

Uiteindelik gaan dit oor ' $n$ juiste korrelasie tussen die regte verstaan van die evangelie, wat impliseer 'n sáámverstaan daarvan (Ef. 3:18), insig in die (sosiale) konteks, asook die leiding van die Gees van God, waarby die gebed om leiding van die Gees ingesluit word. Woord en werklikheid 
word sodanig op mekaar betrek dat die Woord in die werklikheid ingaan sonder om daarin op te gaan. Sodoende word die konteks volledig verreken maar sonder om daaraan prioriteit te verleen.

Ten slotte kan die verhouding tussen geloof en etnisiteit beskryf word as kritiese assosiasie: assosiasie, omdat 'n teoloog en Christen in ' $n$ bepaalde konteks leef en werk waarvan dit onmoonlik is om hom/haar te dissosieer en wat sy/haar leefwyse en teologisering kleur; krities, omdat geen teoloog en Christen hom/haar ooit onvoorwaardelik en onkrities met daardie kulturele konteks behoort te identifiseer en dit as normatief vir kerk en teologie te aanvaar nie.

\section{Bibliografie}

ANON. 1995. Ethnicity and nationalism: A challenge to the churches. The Ecumenical Review, 47(2):225-231, April.

ACTA GKSA. 1985. Handelinge van die Nasionale Sinode van die Gereformeerde Kerke in Suid-Afrika. Pothcefstroom : Administratiewe Buro.

ACTA GKSA. 1991. Handelinge van die Nasionale Sinode van die Gereformeerde Kerke in Suid-Afrika. Potchefstroom : Administratiewe Buro.

AUGUSTINUS. Augustinus van Hippo: Preken over de eerste brief van Johannes. Leuven: Augustijns Historisch Instituut. (Vert. T.J. van Bavel). 1992.

AUGUSTINUS. Retractationes. kyk Perl.

BERKOUWER, G.C. 1970. De Kerk I: Eenheid en katholiciteit. Kampen : Kok.

BERKOUWER, G.C. 1972. De Kerk II : Apostoliciteit en heiligheid. Kampen : Kok.

BREYTENBACH, C., red. 1987. Eenheid en konflik: eerste beslissinge in die geskiedenis van die Christendom. Pretoria : NGKB.

BRUCE, F.F. 1974. Commentary on the book of the Acts. Grand Rapids : Eerdmans.

BROWN, P. 1969. Augustine of Hippo: a biography. Berkeley : University of California.

CALVIJN, J. 1899. De Handelingen der Apostelen I. Kampen : Kok. (Vert. G. Wielenga.)

CALVIN. 1977. Institutes of the Christian religion I-II. Philadelphia : The Westminster Press. (Transl. F.L. Battles.)

CARROLL, R.P. 2000. (South) Africa, Bible, criticism: Rhetorics of a visit. Journal of Theology for Southern Africa, 108:39-53, Nov.

CHADWICK, H. 1996. Augustine. Oxford : Oxford University Press.

COETZEE, J.C. 1965. Volk en Godsvolk in die Nuwe Testament. Potchefstroom : Pro Rege Pers.

D'ASSONVILLE, V.E. 1977. Totius - profeet van die Mooirivier: 'n Lewenskets van prof. dr. J.D. du Toit. Kaapstad: Tafelberg.

D'ASSONVILLE, V.E. 1993. Dit is Totius - J.D. du Toit 1977-1953. Lynnwoodrif : Marnix.

DEIST, F. 1994. Ervaring, rede en metode in Skrifuitleg. Pretoria : RGN.

DE KLERK, W.J. 2000. Afrikaners: Kroes, kras, kordaat. Kaapstad : Human \& Rousseau.

DE VILLIERS, J.L. 1977. Die Handelinge van die apostels I. Kaapstad : NG KerkUitgewers. 
DOUMA, J. 1990. Christus en cultuur. (In Douma, J., Trimp, C. \& Veling, K., red. K. Schilder: Aspecten van zijn werk. Barneveld : De Vuurbaak. p. 169-201.)

DU TOIT, J.D. 1977. Totius Versamelde Werke 7: Die staat, maatskappy, taal en kultuur. Kaapstad : Tafelberg.

DU TOIT, J.D. \& DU TOIT, S. 1955. Die Afrikaanse rassebeleid en die Skrif. Potchefstroom : Pro Rege Pers.

FITZGERALD, A.D. 1999. Circumcellions. (In Fitzgerald, A.D., ed. Augustine through the ages: An encyclopedia. Grand Rapids : Eerdmans. p. 193-194.)

FREND, W.H.C. 1952. The Donatist church: A movement of protest in Roman North Africa. Oxford : Clarendon Press.

FREND, W.H.C. 1985. The Donatist church - forty years on. (In Landman, C. \& Whitelaw, D.P., ed. Windows on origins: Essays on the early church in honour of J.A.A.A. Stoop on his sixtieth birthday. Pretoria : Unisa. p. 70-84.)

GOOTJES, N.H. 1995. Schilder on Christ and culture. (In Geertsema, J., ed. Always obedient: Essays on the teachings of Dr. Klaas Schilder. Phillipsburg NJ : Reformed Publishing. p. 35-64.)

GRASMÜCK, E.L.1964. Coercitio: Staat und Kirche in Donatistenstreit. Bonn : Röhrscheid.

HARRISON, E.F. 1975. Acts: The expanding church. Chicago : Moody Press.

HARRISON, E.F. 2000. Augustine: Christian truth and fractured humanity. Oxford : University Press.

JOUBERT, S.J. 1991. Voort met die nuwe bedeling: Handelinge as 'n paranetiese narratief binne 'n kosmopolitiese Christelike gemeenskap. (In Roberts, J.H. et al., red. Teologie in konteks: Opgedra aan prof. A.B. du Toit. Halfway House : Orion. p. 131-155.)

KISTEMAKER, S.J. 1990. New Testament Commentary: Exposition of the Acts of the Apostles. Grand Rapids : Eerdmans.

KÜNG. H. 1967. De kerk. Hilversum : Paul Brand.

LOHSE, E. 1969. Prósopon et al. (In Friedrich, G., ed. Theological Dictionary of the New Testament 6. Grand Rapids : Eerdmans. p. 768-780.)

MARKUS, R.A. 1999. Donatus/Donatism. (In Fitzgerald, A.D., ed. Augustine through the ages: An encylopedia. Grand Rapids : Eerdmans. p. 284-287.)

MARSHALL, I.H. 1989. The Acts of the Apostles: An introduction and commentary. Grand Rapids : Eerdmans.

McGOLDRICK. J.E. 2000. God's renaissance man: The life and work of Abraham Kuyper. Auburn/Mass : Evangelical Press.

MOLTMANN, J. 1975. Kirche in der Kraft des Geistes: Ein Beitrag zur messianischen Ekklesiologie. München : Kaiser.

NIEBUHR, H.R. 1956. Christ and culture. New York : Harper \& Row.

NOORDMANS, O. 1933. Augustinus. Haarlem : Bohn.

NOORDMANS, O. 1986. Verzamelde werken 6: De kerk en het leven. Kampen : Kok.

OBERHOLZER, J.P. 1999. Terug op die pad. (In Van Wyk, D.J.C., red. 20ste eeu Hervormde Teologie. Pretoria : Sentik. p. 449-461.)

PERL, C.J. 1976. Aurelius Augustinus: Die Retractationen in zwei Büchern. Padenhorn : Ferdinand Schöningh.

POLHILL, J.B. 1992. The New American Commentary 26: Acts. Nashville/Tennesee : Broadman Press.

POSSIDIUS. 1988. The life of saint Augustine. Villanova PA : Augustinian Press. (Ed. J.R. Rotelle.)

RACKHAM, R.B. 1957. The Acts of the Apostles. Londen : Methuen. 
RIST, J.M. 1999. Augustine: Ancient thought baptized. Cambridge : Cambridge University Press.

RUSSELL, W.P. 1995. Contextualization: Origins, meaning and implications. Rome : Pontificia Studiorum Universitas.

SCHILDER, K. 1948. Christus en cultuur. Franeker : Wever.

SIZOO, A. 1957. Augustinus: Leven en werken. Kampen : Kok.

SMIT, M.C. 1987. Culture and salvation. (In Van Dyke, H., ed. Writings on God and history I. Ontario : Wedge Publishing Foundation. p. 115-142.)

SNYMAN, W.J. 1977. Nuwe en ou dinge: Uit die skat van die koninkryk. Potchefstroom : Pro Rege Pers.

STOKER, H.G. 1941. Die stryd om die ordes. Potchefstroom : CJBF.

STOKER, H.G. 1967. Oorsprong en rigting. Kaapstad : Tafelberg.

STOTT, J. 1990. Issues facing Christians today: New perspectives on social and moral dilemmas. London : Marshall Pickering.

TENGSTRÖM, E. 1964. Donatisten und Katholiken. Goteborge : Almquist \& Wiksell.

THERON, P.F. 1988. Natuur en genade, kerk en volk. (In Wethmar, C.J. \& Vos, C.J.A., red. 'n Woord op sy tyd: 'n Teologiese feesbundel aangebied aan professor Johan Heyns ter herdenking van sy sestigste verjaarsdag. Pretoria : NGKB. p. 157-171.)

THOM, G. 2000. Christ, the transformer of culture? Studia Historiae Ecclesiasticae, 26(2):50-68.

TRCSA. 1998. Truth and Reconciliation Commission of South Africa Report 4. Kaapstad : Juta.

VAN DER KOOI, C. \& DE BRUIJN, J., eds. 1999. Kuyper reconsidered: Aspects of his life and work. Amsterdam : VK-Uitgeverij.

VAN DER WALT, B.J. 1993. Human dignity and identity: According to apartheid and according to the Word of God. (In Waijaki, M., Turaki, Y. \& Van der Walt, B.J. Visions of man and freedom in Africa. Potchefstroom : PUCHE/IRS. p. 29-52.)

VAN DER WALT, B.J. 1994. The liberating message: A Christian worldview for Africa. Potchefstroom : PUCHE.

VAN DER WALT, B.J. 1995. Hand in eie boesem: 'n Besinning oor Afrikaneridentiteit. Potchefstroom : IRS.

VAN DER ZWAAG, K. 1993. Augustinus, de kerkvader van het westen. Leiden : Groen \& Zoon.

VAN GENDEREN, J. 1993. Naar de norm van het Woord. Kampen : Kok.

VAN OORT, J. 1990. Augustinus over de kerk. (In Van't Spijker, W. et al., red. De kerk: Wezen, weg en werk van de kerk naar reformatorische opvatting. Kampen : De Groot Goudriaan. p. 65-94.)

VAN RULER, A.A. 1969. Theologisch werk I. Nijkerk : Callenbach.

VAN'T SPIJKER, W. et al., red. 1990. De kerk: Wezen, weg en werk van de kerk naar reformatorische opvatting. Kampen : De Groot Goudriaan.

VAN WYK, J.H. 1985. Man van die derde weg: W.J. Snyman as teoloog. Potchefstroom : PUCHO/IRS.

VAN WYK, J.H. 1990. Geroep tot eenheid. (In Du Toit, H. \& Kruger, P., red. Geroep tot eenheid. Halfway House : NGKB. p. 6-30.)

VAN WYK, 1991. Moraliteit en verantwoordelikheid: Opstelle oor politieke etiek. Potchefstroom : PUCHO.

VAN WYK, J.H. 1993. Homo Dei: 'n Prinsipiële besinning oor enkele mensbeskouings waaronder dié van Calvyn. Supplementum 1. In die Skriflig,

VAN WYK, J.H. 1994. Liberale konserwatisme? H.G. Stoker en die ideologie van apartheid: 'n Verkenning. Koers, 59(3 \& 4):435-454. 
VAN WYK, J.H. 1995. Die relevansie van die gereformeerde teologie vir vandag. In die Skriflig, 29(1 \& 2):241-268.

VAN WYK, J.H. 1998. Etiek in eenvoud: Gesprekke oor morele vraagstukke. Potchefstroom : PTP.

VAN WYK, J.H. 1999. Skuldbelydenis in teologiese perspektief. In die Skriflig, 33(2):203-224.

VEENHOF, J. 1994. The relationship between nature and grace according to $H$. Bavinck. Potchefstroom : IRS (no. 322).

VELDHUIZEN, P. 1995. God en mens onderweg: Hoofdmomenten uit de theologische geschiedbeshouwing van Klaas Schilder. Leiden : Groen \& Zoon.

WEIJLAND, H. 1965. Augustinus en de kerkelijke tucht: Een onderzoek naar de grensen van de kerk bij Augustinus tegen de achtergrond van het donatistisch schisma. Kampen : Kok.

WENTSEL, B. 1970. Natuur en genade: Een introductie. Kampen : Kok.

WILLIS, G.G. 1958. Saint Augustine and the Donatist controversy. Londen : SPCK.

\section{Kernbegrippe:}

apartisme

Donatisme

etnisiteit, kontekstualiteit, kerk; relasie en relevansie

Judaïsme

kontekstualiteit, etnisiteit, kerk: relasie en relevansie

\section{Key concepts:}

apartism

contextuality, ethnicity, church: relation and relevance

Donatism

ethnicity, contextuality, church: relation and relevance

Judaism 